ERRATUM

Erratum doi: https://doi.org/10.1007/s00376-020-0012-z

\title{
Erratum to: Predicting June Mean Rainfall in the Middle/Lower Yangtze River Basin
}

\author{
Gill M. MARTIN*, Nick J. DUNSTONE, Adam A. SCAIFE, and Philip E. BETT \\ Met Office, Exeter, Devon EX1 3PB, United Kingdom
}

ESM to: Martin, G. M., N. J. Dunstone, A. A. Scaife, and P. E. Bett, 2020: Predicting June mean rainfall in the middle/lower Yangtze River basin. Adv. Atmos. Sci., 37(1), 29-41, https://doi.org/10.1007/s00376-019-9051-8.

The article [Predicting June Mean Rainfall in the Middle/Lower Yangtze River Basin], written by [Gill M. MARTIN, Nick J. DUNSTONE, Adam A. SCAIFE, and Philip E. BETT], was originally published electronically on the publisher's internet portal on [10 December 2019] without open access. With the author(s)' decision to opt for Open Choice, the copyright of the article changed to (C) Crown 2020.

This article contains public sector information licensed under the Open Government Licence v3.0, which permits use, sharing, adaptation, distribution and reproduction in any medium or format, as long as you give appropriate credit to the original author(s) and the source, provide a link to the Open Government licence, and indicate if changes were made. The images or other third party material in this article are included in the article's Open Government licence, unless indicated otherwise in a credit line to the material. If material is not included in the article's Open Government licence and your intended use is not permitted by statutory regulation or exceeds the permitted use, you will need to obtain permission directly from the copyright holder. To view a copy of this licence, http://www.nationalarchives.gov.uk/doc/open-governmentlicence/version/3/

The original version has been updated.

The online version of this original article can be found at https://doi.org/10.1007/s00376-019-9051-8.

\footnotetext{
* Corresponding author: Gill M. MARTIN

Email: gill.martin@metoffice.gov.uk
} 